Çukurova Üniversitesi Mühendislik Mimarlık Fakültesi Dergisi, 31(ÖS 1), ss. ÖS 43- ÖS 49, Ağustos 2016 Çukurova University Journal of the Faculty of Engineering and Architecture, 31(ÖS 1), pp. SI 43-SI 49, August 2016

\title{
Kondansatör Deşarjli Saplama Kaynağı Kaynak Voltunun Aa6082 Alüminyum Alaşımında Birleşmeye Etkisi

\author{
Mehmet ÇAKMAKKAYA ${ }^{* 1}$, Ahmet YÖNETKEN ${ }^{2}$, Ayhan EROL $^{3}$ \\ ${ }^{1}$ Afyon Kocatepe Üniversitesi, Teknoloji Fakültesi, Otomotiv Mühendisliği Bölümü, \\ Afyonkarahisar \\ ${ }^{2}$ Afyon Kocatepe Üniversitesi, Mühendislik Fakültesi, Elektrik Mühendisliği Bölümü, \\ Afyonkarahisar \\ ${ }^{3}$ Afyon Kocatepe Üniversitesi, Teknoloji Fakültesi, Metalürji ve Malzeme Mühendisliği Bölümü, \\ Afyonkarahisar
}

Geliş tarihi: 29.12 .2015

Kabul tarihi: 30.03 .2016

\section{Özet}

Bu çalışmada Ø4 mm standart alüminyum saplamalar kullanılarak 6082 Alaşımı farklı volt ayarlarında kaynaklanmıştır. Düşük ve yüksek volt değerlerinde yapılan saplamalarda birleşme zayıf ve yada hiç sağlanamamıştır. Fakat saplama çapına uygun seçilen volt değerlerinde $(150 \mathrm{~V}$ ve $160 \mathrm{~V})$ ise kaynak bölgesinde kopma olmadan yapılan bağlantı saplamaları kendi ekseninde doksan derece eğilerek test edilmiştir.

Anahtar Kelimeler: Alüminyum alaşımları, Isıl işlem, Saplama kaynağı, TIG ve MIG kaynakları

\section{Joint Of Aa 6082 T6 Aluminium Alloy By Welded Capacitor Discharge Stud Welding Technique}

\begin{abstract}
In this study, Aluminum Alloys of aluminum stub using a standard $4 \mathrm{~mm}$ in diameter resulted in different source voltage. Low and high voltage junction studs made from combining weak or not provided at all. But the stud diameters according to the selected source voltage value in combining with the studs are tested leaning ninety degrees on its axis. $150 \mathrm{~V}$ and $160 \mathrm{~V}$ has been shown to bend without breakage of stud welding voltage
\end{abstract}

Keywords: Aluminum alloys, Heat treatment, Stud Welding, TIG and MIG welds

\footnotetext{
* Sorumlu yazar (Corresponding author) : Mehmet ÇAKMAKKAYA, Afyon Kocatepe Üniversitesi, Teknoloji Fakültesi, Otomotiv Mühendisliği Bölümü, Afyonkarahisar, cakmakkaya@aku.edu.tr
} 


\section{INTRODUCTION}

Aluminum alloy as forging and casting alloys are divided into two groups. A wrought alloy, plastic deformation capability is good can be formed easily. Aluminum forging and heat treatment can be applied to a large portion of the cast alloy. 6xxx series aluminum alloy as the main alloying elements of magnesium and silicon. This alloy element found in certain ratios, chemical composition morphology and structural components has a significant impact on beneficial properties [1], [2], [3], [4] and [5]. Besides the added intentionally made to commercial aluminum alloy in such transition metals such as $\mathrm{Fe}$ and $\mathrm{Mn}$ alloys, it is always available. Large amounts of these impurities in the non-phase causes the formation of certain new components [5].

The formation of their composition and microstructure affect the status of the re-formed the most important factor is that how do casting. This will directly affect the number of phases formed and volume [4].

6xxx series aluminum alloys during casting, the phase of $\mathrm{Al}-\mathrm{Fe}, \mathrm{Al}-\mathrm{Fe}-\mathrm{Si}$ and $\mathrm{Al}-\mathrm{Fe}-\mathrm{Mn}-\mathrm{Si}$ and $\mathrm{Fe}$ containing intermetallic aluminum dendrites are formed by a wide range [1], [2], [3], [4], [5] and [6]. Formed during this phase of the casting speed and the type of alloy cooling rate depends mainly faze [1]. This unit cell forms the intermetallic phase with a variety of different morphology, stable, has physical and mechanical properties [6]. This study was used 6082 series aluminum alloys used in. Because this series alloys exhibit excellent resistance to corrosion. These have resistance values that are known to be superior to other aluminum alloys. It provides structural integrity against the aluminum series welding process commonly used, but represents a decrease in strength in the weld fusion welding. Arc melting in the welding seams have been made in the work to increase the strength decrease in 4043 using additional welding wire [9]. They tested the strength of the stud using a stud welding done $[7,8]$. Gurjind study by Singh et al showed that the effect of microstructure and hardness of the current violence [9]. In this study condenser discharge welding machine it is used. This method results in a sudden discharge of my sources back in the stud conical nozzle tip to the base metal surface melting occurs sources this region and pushing force of the gun.

During the conduct of the source voltage source and the strength of the force applied to the welding gun may be effective.

\section{EXPERIMENTAL STUDY AND MICROSTRUCTURE ANALYSIS}

Chemical ratio of elements used in the 6082 alloy is given in Table 1 for stud welding. The mechanical properties of these alloys are given in Table 2. Surface preparation the samples were cut in appropriate size from the alloy after 150, as shown in Figure 1, 160, 170 and 200 volt stud welding using voltage values are made.

Table 1. The chemical composition of the 6082 alloy [12]

\begin{tabular}{|c|c|c|c|c|c|c|c|c|c|}
\hline$\%$ & $\mathrm{Cu}$ & $\mathrm{Mn}$ & $\mathrm{Si}$ & $\mathrm{Fe}$ & $\mathrm{Mg}$ & $\mathrm{Cr}$ & $\mathrm{Zn}$ & $\mathrm{Ti}$ & $\mathrm{Al}$ \\
\hline Min & & 0.4 & 0.7 & & 0.6 & & & & \\
\hline Max & 0.1 & 1.0 & 1.3 & 0.5 & 1.2 & 0.25 & 0.2 & 0.1 & Kalan \\
\hline
\end{tabular}

Table 2. The mechanical properties of the 6083

\begin{tabular}{|c|c|c|c|c|c|}
\hline Alloy & $\begin{array}{c}\text { Tensile } \\
\text { Strength } \\
(\mathrm{MPa})\end{array}$ & $\begin{array}{c}\text { Yield } \\
\text { strength } \\
0.2 \% \\
(\mathrm{MPa})\end{array}$ & $\begin{array}{c}\text { Shear } \\
\text { strength } \\
(\mathrm{MPa})\end{array}$ & $\begin{array}{c}\text { Hardness } \\
\text { Vickers } \\
(\mathrm{HV})\end{array}$ & $\begin{array}{c}\text { Elongation } \\
\text { A5 (\%) }\end{array}$ \\
\hline 6082 & 130 & 60 & 85 & 35 & 27 \\
\hline $6082 \mathrm{~T} 6$ & 340 & 310 & 210 & 100 & 11 \\
\hline
\end{tabular}

As shown in Figure 1 high voltages at high energy discharge that occurs in the weld zone by the effect of extremes in temperature reduces the strength of the weld. Because the used stud diameter stud welding machine to get out due to the high voltage from the source region are distributed in more than melts, however, because it consists in welding molten liquid resources from the effects of high voltage. So they could not provide enough strength to unite. The owner of the stud diameter of the resistance value is selected according to the voltage at the source of liquid metal dispersion 
formed from the merger could be achieved provided that the stud member joins or higher strength from him.

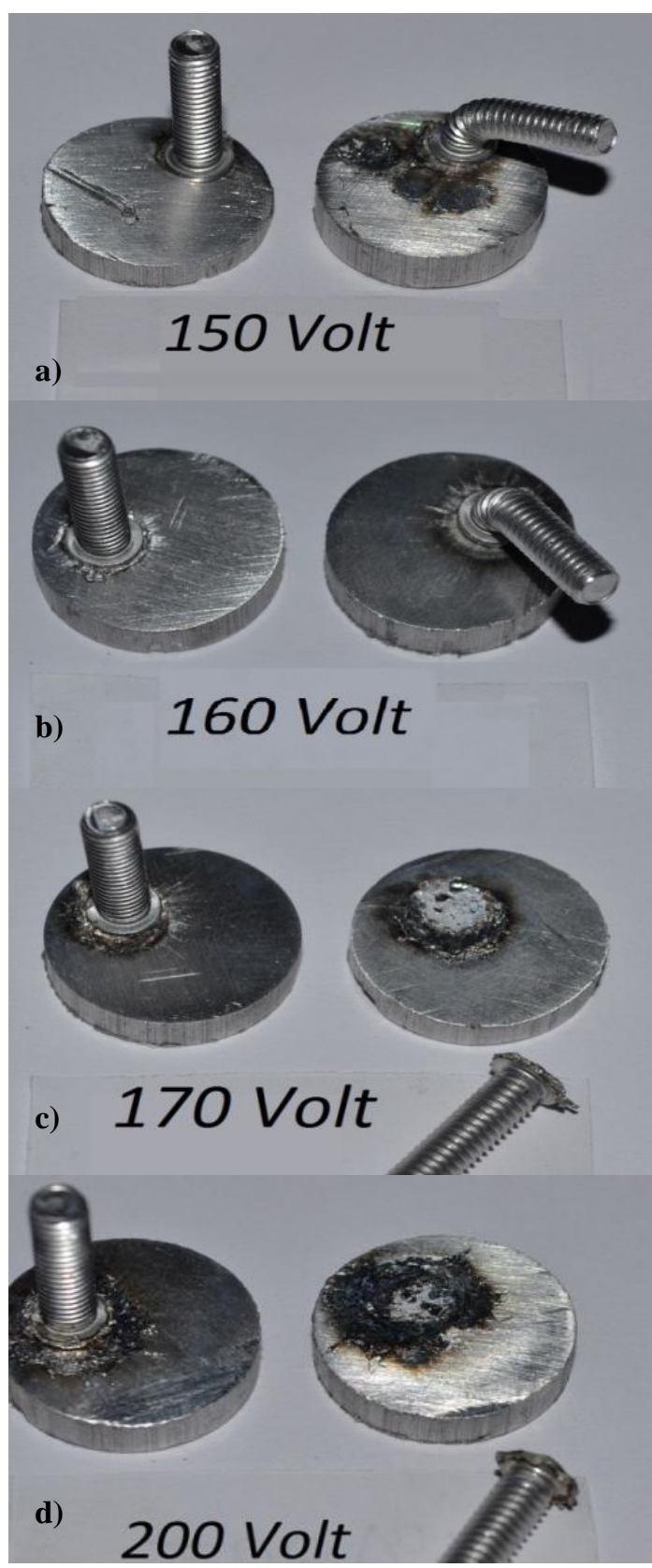

Figure 1. Stud welding image made from different sources volts a) 150 , b) 160 , c) 170, d) 200 Volt
Microhardness measurements performed on samples of stud welding of metal substantially as shown in Figure 2, the hardness values and the stud material from the weld zone is obtained. This measurement in the Micro Hardness test equipment to Shimadzu stuck using a 1,962 N load. This micro hardness values are given in Table 3 with increasing current value in the base metal of the welding process causes a decrease in strength occurs between the coupling studs. Increasing the supply voltage to indicate the source region and the HAZ hardness values can be changed (Figure 3). Get merge with GTAW process was measured to be made here microhardness increase in parallel with increasing current. There are $100 \mathrm{Amps}$ at $75 \mathrm{VHN}$ and main source of metal to metal towards 99.6 VHN, 240 VHN of 55.8 amps were also measured as the value rises to $95.2 \mathrm{VHN}$ [9].

This work is seen in the table which is subject to change microsutructural 3 parallel to the increasing source of tension. Due to the increase in the value of the supply voltage can occur in low voltage high welding strength in combining confirms this idea.

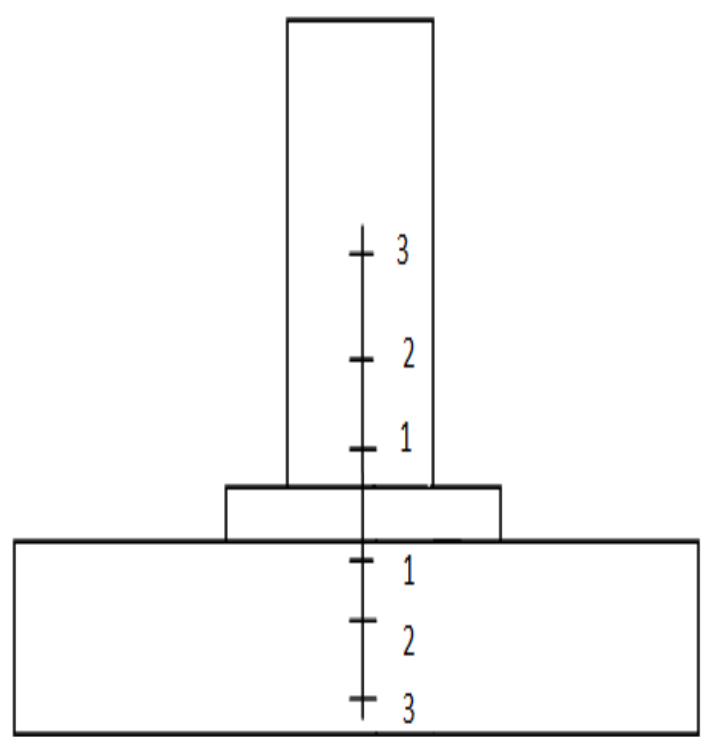

Figure 2. Base metal and studs and micro hardness measurement reference points 
Table 3. Micro-hardness values depending on the

\begin{tabular}{|c|c|c|c|c|c|}
\hline $\begin{array}{l}\text { Sample } \\
\text { Name }\end{array}$ & $\begin{array}{c}\text { Source } \\
\text { Voltage }\end{array}$ & \multicolumn{2}{|c|}{$\begin{array}{c}\text { Main Metal } \\
\mathrm{HV}_{0,2}\end{array}$} & \multicolumn{2}{|c|}{ Stud $\mathrm{HV}_{0,2}$} \\
\hline \multirow{12}{*}{6082} & \multirow{3}{*}{150} & 1 & 79,6 & 1 & 67,9 \\
\hline & & 2 & 84,1 & 2 & 63,3 \\
\hline & & 3 & 89,8 & 3 & 68,2 \\
\hline & \multirow{3}{*}{160} & 1 & 97 & 1 & 58 \\
\hline & & 2 & 114 & 2 & 74 \\
\hline & & 3 & 104 & 3 & 65,5 \\
\hline & \multirow{3}{*}{170} & 1 & 96,7 & 1 & 87,2 \\
\hline & & 2 & 97,7 & 2 & 80 \\
\hline & & 3 & 108 & 3 & 84,3 \\
\hline & \multirow{3}{*}{200} & 1 & 112 & 1 & 60,9 \\
\hline & & 2 & 115 & 2 & 67,4 \\
\hline & & 3 & 131 & 3 & 62 \\
\hline
\end{tabular}

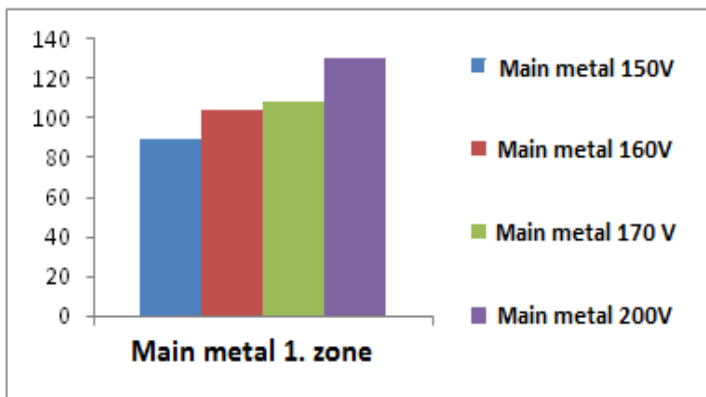

Figure 3. Zone 1 main metal of different hardness change of the voltage source

\subsection{Microstructure of Welded Joints and Stiffness Analysis}

Combine with increased supply voltage in stud welding, the main interface with the metal stud (in source zone) shows brittle fracture behavior in difficulty bending the stud member. The agglomerate of creep rupture of the show instead of honey honeycomb shaped fracture behavior is observed in the SEM micrograph. Figures $(6,7)$ GTAW welding of the same alloy formed in the interlocking and inter dendritic dendritic structures can lead to decreased strength. The increase in heat input by increasing the welding current has been shown to lead to increased dendritic and interdendritic regions $[9,10]$. Stud welding fluid of joints made with very low volume and dendritic weld metal cooling rate is high, however, and inter lying solidify without the formation of dendritic structure are contemplated. S the best place for stud welding stud and base metal merge or close to the same origin when they have a better quality of composition can be achieved.
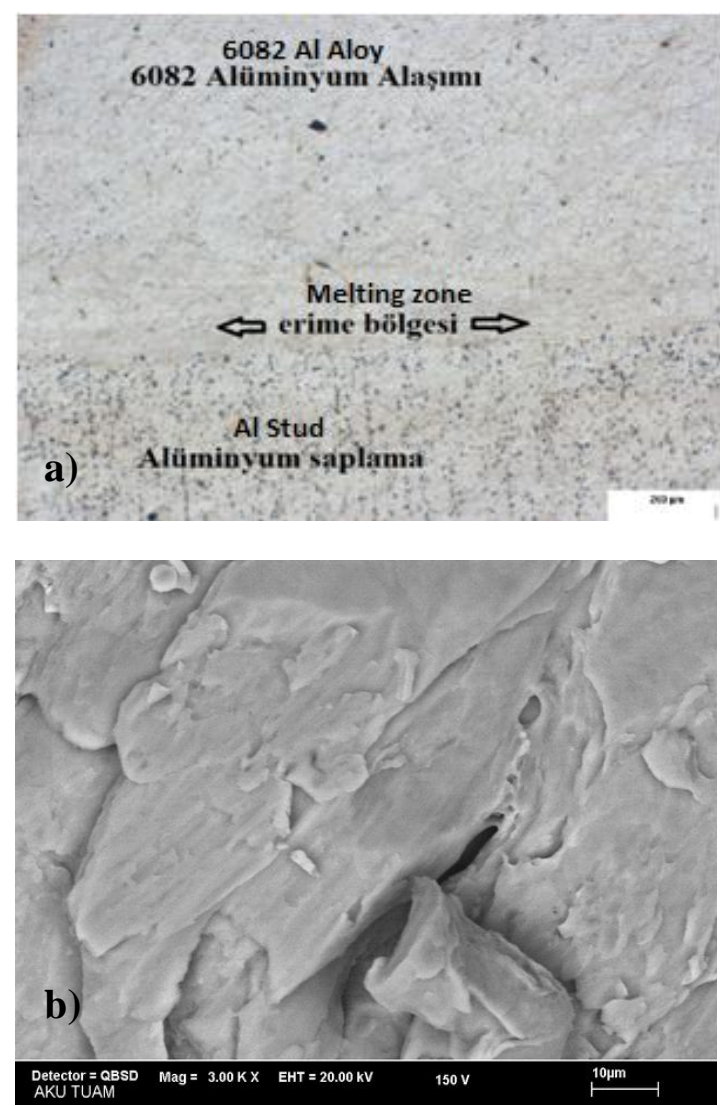

Figure 4. Supply voltage of 150 volts a) optical microstructure b) SEM image of avulsion fracture surface 

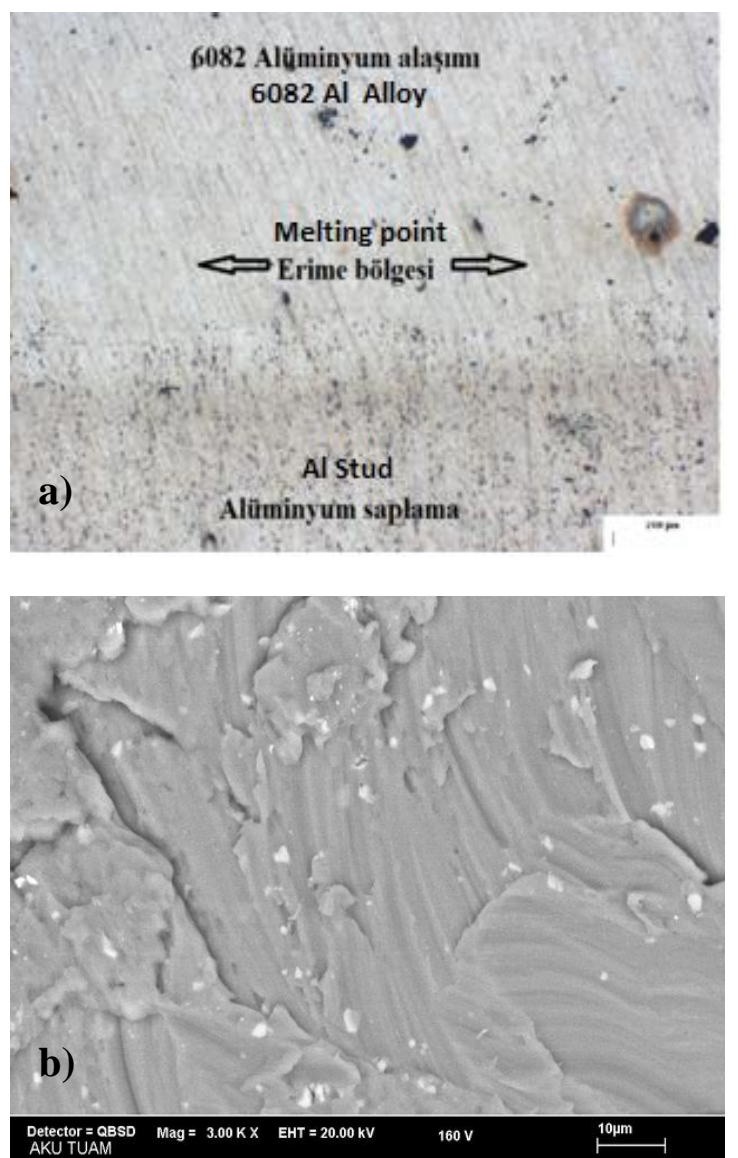

Figure 5. Supply voltage of 160 volts a) optical microstructure b) SEM image of avulsion fracture surface

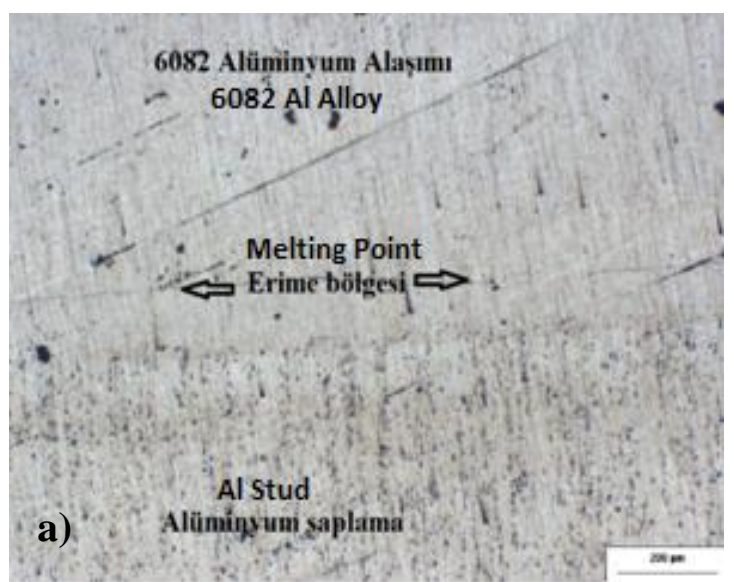

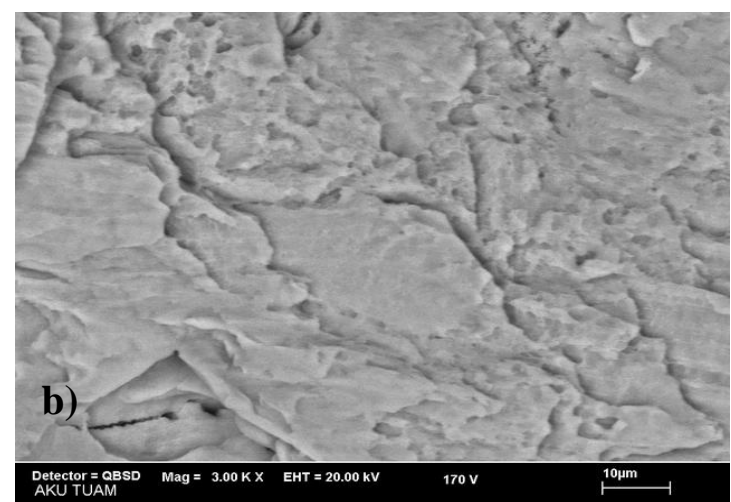

Figure 6. Supply voltage of 170 volts a)optical microstructure b) SEM image of avulsion fracture surface
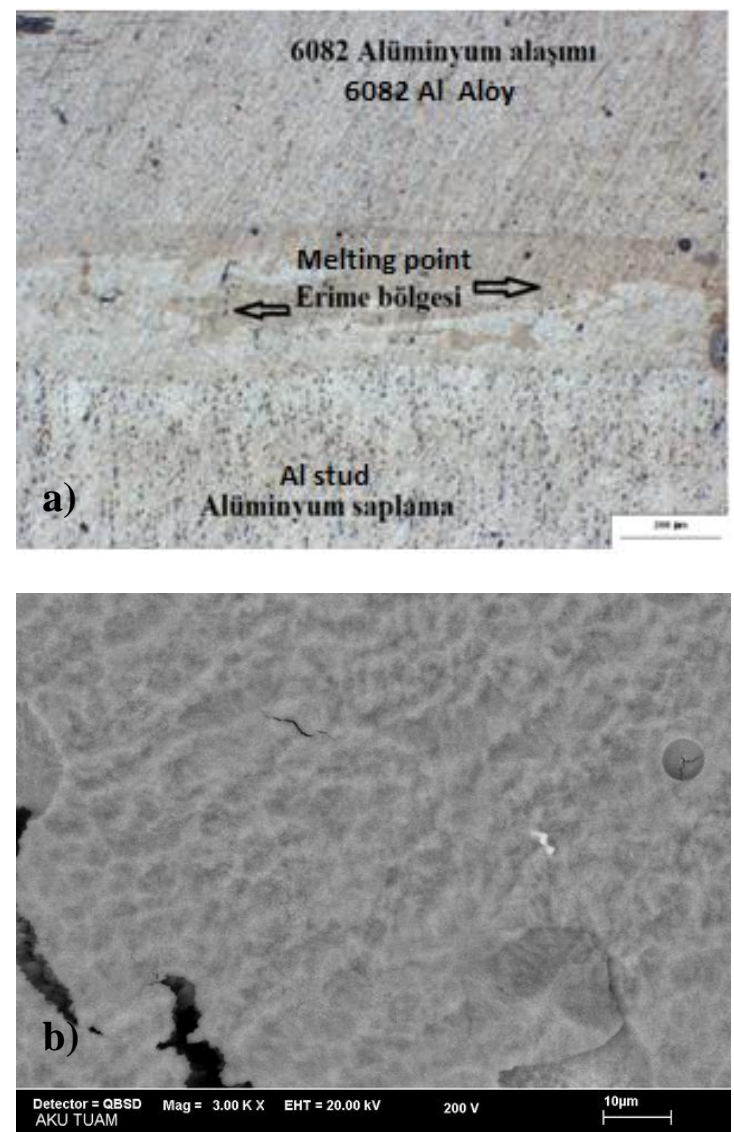

Figure 7. Supply voltage of 160 volts) optical microstructure b) SEM image of avulsion fracture surface 
Welded joints obtained from the results of the experimental work are given in Figure 1. Photos pictures in the work they are doing with Harry A. Chambers (Figure 7) were compared. Here, the effect of increasing the supply of quality welded joints can be observed in current values.

\section{RESULTS AND DISCUSSION}

Capacitor discharge arc stud welding with these studies, in addition to this effect, and resource discovery and depth of penetration of the welding current is determined formation of fragile regions. The most important of the factors affecting the depth of penetration of the related material was found to be the source of tension. I SIMARDZIC and his friends study in stud welding the welding current penetration of effective parameters, time and resources are expressed in the resulting metal geometry [11]. However, the power supply unit capacitor discharge time is used for stud welding in this study it should have been selected fixed in all applications. Search stud welding, especially when the surface hardness accurate analysis and evaluation of the main metal was found to be effective on the hardness change of the voltage source. Correspond to the diameter of the stud welding current can be used and results in more value near the strength of the stud used the strength of the coupling is selected. With stud in high-voltage supply source material consisting of an increase in the hardness between the weld interface consists of a crisp break.

\section{CONCLUSION}

1. Suitable welding voltage used the stud of selected the diameter suitable increases the strength of the Join

2. Surface material between the stud in the weld metal formed the high supply voltage welding material of brittle fracture it consists

3. TIG welding method in the base metal thickness as well as in the MIG process need for preheating occurs of removing the stud welding can be performed without pre-heating welding.

\section{REFERENCES}

1. Michna, S. et al., 2005. Encyclopedia of Aluminium. Prešov: Adin s.r.o. ISBN 8089041-88-4, (in Slovak).

2. Sperlinkş K., 2003. The Future Use of Aluminum and Aluminum Alloys. Proceeding of Aluminium 2003, Desin: Strelnice.

3. Mathers, G., 2002. The welding of aluminium its alloys. Cambridge England, CRC Press, Boca Raton Boston New York Washington, Dc Woodhead Publishing Limited.

4. Cavaliere, P. Santis, A. Panella F., 2009 Thermoelasticity and CCD analysis of crack propagation in AA6082 friction stir welded joints, International Journal of Fatigue 31, pp. 385-392.

5. Kumar, A. Sundarrajan S., 2009. Optimization of pulsed TIG welding process parameters on mechanical properties of AA5456 Aluminium alloy weldments", Journal of Materials and Design Vol. 30, pp. 1288-1297.

6. Cabello Munoz, A., Ruckert, G., Huneau, B., Sauvage, X., Marya, S., 2008. Comparasion of TIG welded and friction stir welded Al-4.5Mg$0.26 \mathrm{Sc}$ alloy, Journal of materials processing technology Vol. 197, pp. 337-343.

7. Strigel, Roberta M., Pincheira, José A., and Oliva, Michael G., 2000. Reliability of 3/8 in. Stud-Welded Deformed Bar Anchors Subject to Tensile Loads, PCI JOURNAL, V. 45, No. 6, November-December, pp. 72-82.

8. Anderson, Neal S., and Meinheit, Donald, F., 2000. Design Criteria for Headed Stud Groups in Shear: Part 1 - Shear Capacity and Back Edge Effects," PCI JOURNAL, V. 45, No. 5, September-October, pp. 36-75.

9. Gurjinder S., Sunil K., Amrik S., 2013. Influence of current on microstructure and hardness of butt welding aluminum AA6082 using GTAW process" IJRMET vol.3, Issue 2, May-Oct.

10. Harry A., 1988. Chambers Stud Welding Applications: Concrete Connections, Nelson Stud Welding, Inc., Elyria, OH.

11. I. SAMARDZIC et al., 2009. The influence of welding parameters on weld characteristics in 
electric arc stud welding METABK 48(3) 181186.

12. http://seykoc.com.tr/aluminyumalasimlar/6082.aspx., Seykoç Alüminyum., erişim tarihi 26.12.2015. 
